\title{
7 he German Invasion of Norway, April-June 1940: Romanian Echoes
}

\section{Bogdan-Alexandru Schipor}

"A.D. Xenopol" Institute of History of the Romanian Academy, E-mail: bogdan_schipor@yahoo.it

\section{Abstract}

We can all agree that World War II, beyond its military, political or economic coordinates, countless tragedies, convulsions propagated around the world, tensions and dramas often felt to our day, was for all of us a lesson of geography. From this perspective, the invasion of Poland in September 1939 by the German and Soviet troops was a first lesson, continued on another level by the Soviet-Finnish Winter War. The invasion of Norway (and Denmark) by the Germans in April 1940, followed by the allied reaction and the transformation of the Scandinavian states into a theatre of military operations, was monitored with distinct interest in Romania, at political, diplomatic and military level, but also at the level of general perception of a society that was both worried and avid, in the context of the European (for the time being) war, of information on the evolution of the conflict and not only. Names such as Oslo, Narvik, Trondheim, Åndalsnes, Namsos, Bergen, Lillehammer, Stavanger or Tromsø become familiar to the Romanian public. We find, especially in the Romanian media of the time, a luxurious abundance of accounts, commentaries, editorials, telegrams or interviews related to the conduct of military operations in northern Europe, beyond the

\section{Rezumat}

Putem fi cu toții de acord asupra faptului că al doilea război mondial, dincolo de desfăşurarea sa pe coordonate militare, politice sau economice, de tragediile fără număr, de convulsiile propagate la nivelul întregii lumi, de tensiunile și dramele resimțite adesea până în zilele noastre, a fost pentru noi toți și o lecție de geografie. Din această perspectivă, invadarea Poloniei din septembrie 1939 de către trupele germane și sovietice a fost o primă lecție, continuată, la un alt nivel, de Războiul de Iarnă sovieto-finlandez. Invadarea Norvegiei (și Danemarcei) de către germani, din aprilie 1940, urmată de reacția aliată și transformarea statelor scandinave într-un teatru de operațiuni militare a fost urmărită $\mathrm{cu}$ un deosebit interes în România, atât la nivel politic, diplomatic și militar, dar și la nivelul percepției generale a societății, îngrijorate și avidă, în contextul războiului, european deocamdată, de informații cu privire la evoluția conflictului și nu numai. Iar nume precum Oslo, Narvik, Trondheim, Andalsnes, Namsos, Bergen, Lillehammer, Stavanger sau Tromsø devin familiare publicului român. Descoperim, mai ales în presa românească a vremii, o bogăție luxuriantă de relatări, comentarii, editoriale, telegrame sau interviuri legate de desfăşurarea operațiunilor militare din nordul Europei, dincolo de cenzura 
censorship and restrictions imposed by the conditions of the war. From this perspective, we find it difficult to attempt even to pursue the conflict in Norway in April-May 1940 only in the light of articles in the Romanian press. Central newspapers, in the first place, abound with telegrams that alternately feature views, news, and information from both camps. Inevitably there were various denials, rumors, or what we call today "fake news", often taken over by the sensational rush, even by big press agencies of the time, without mentioning newspapers in European capitals including Bucharest. For this reason, our objective is to identify and analyze some of the Romanian echoes generated by the invasion of Norway, both in the Romanian media, but also at a diplomatic or military level, in a context in which Romania, as a neutral state, lived its own tensions and worries about its future fate as the war spread across the old continent. și restricțiile impuse de condițiile războiului. Din această perspectivă, considerăm dificilă o eventuală încercare de a urmări desfășurarea conflictului din Norvegia din aprilie-mai 1940 doar prin prisma articolelor din presa românească. Ziarele centrale, în primul rând, abundă de telegrame care prezentau, alternativ, puncte de vedere, știri și informații din ambele tabere. Inevitabil apăreau diverse dezmințiri, zvonuri sau ceea ce astăzi numim "știri false", preluate adesea, în goana după senzațional, chiar de mari agenții de presă ale timpului, fără a mai vorbi de ziarele din capitalele europene, inclusiv București. Din acest motiv, obiectivul nostru este acela de a identifica și analiza câteva dintre ecourile românești generate de invazia Norvegiei, atât în presa românească, dar și la nivel diplomatic sau militar, într-un context în care România, ca stat neutru, trăia propriile tensiuni și îngrijorări cu privirea la soarta sa viitoare $\hat{\imath}$ condițiile în care râzboiul se întindea pe bătrânul continent.

Keywords: World War II, German invasion, Norway, Scandinavian States, Romania, Allies CC BY-SA License (https://creativecommons.org/licenses/by-sa/2.0)

This paper was presented at the "Norway 100" Seminar hosted by "Al. I. Cuza” University of Iași and co-organized with the Norwegian Centre for International Cooperation in Higher Education, the Romanian Association for Baltic and Nordic Studies and the Department of Germanic Studies in Iaşi on November 18, 2017 to mark 100 years of diplomatic relations between Romania and Norway.

It has been often said that World War II, beyond its military, political or economic coordinates, countless tragedies, convulsions propagated around the world, tensions and dramas often felt to our day, was for all of us a lesson of geography. How else could it be justified that most of those passionate or interested in the great conflagration, or who have transitorily and compulsorily studied it in schools have heard of Guadalcanal and Benghazi, Tobruk and Stalingrad, Kursk and Casablanca, Viipuri or Khania, Tolvajärvi Rio de la Plata, to give just a few random examples of names without which the history of that war could not be complete? From 
this perspective, the invasion of Poland in September 1939 by the German and Soviet troops was a first lesson, continued on another level by the Soviet-Finnish Winter War. At least at the level of the perceptions of the Romanian society, in all its spheres, the Winter War and the general sympathy wave for the Finnish cause it generated probably constituted the first important window actually opened in Romania to the Nordic society and Scandinavia, the first opportunity to discover a whole world, otherwise quite exotic and marginal.

However, the Soviet neighborhood and the related danger connecting Finland to Romania at that time diluted and diminished to some extent the discovery of "the other", the immediate interest being focused on the outcome of the war and its profound consequences, including for SouthEast Europe. The invasion of Norway (and Denmark) by the Germans in April 1940, followed by the allied reaction and the transformation of the Scandinavian states into a theater of military operations, was monitored with distinct interest in Romania, at political, diplomatic and military level, but also at the level of general perception of a society that was both worried and avid, in the context of the European (for the time being) war, of information on the evolution of the conflict and not only. Names such as Oslo, Narvik, Trondheim, Åndalsnes, Namsos, Bergen, Lillehammer, Stavanger or Tromsø become familiar to the Romanian public. We find, especially in the Romanian media of the time, a luxurious abundance of accounts, commentaries, editorials, telegrams or interviews related to the conduct of military operations in northern Europe, beyond the censorship and restrictions imposed by the conditions of the war. From this perspective, we find it difficult to attempt even to pursue the conflict in Norway in April-May 1940 only in the light of articles in the Romanian press. Central newspapers, in the first place, abound with telegrams that alternately feature views, news, and information from both camps. Inevitably there were various denials, rumours, or what we call today "fake news", often taken over by the sensational rush, even by big press agencies of the time, without mentioning newspapers in European capitals including Bucharest. For this reason, our objective is to identify and analyze some of the Romanian echoes generated by the invasion of 
Norway, both in the Romanian media, but also at a diplomatic or military level, in a context in which Romania, as a neutral state, lived its own tensions and worries about its future fate as the war spread across the old continent.

In order to understand the source of these concerns, it is necessary to analyze why Norway, practically a neutral state in 1940, was mixed in the games and the conflict between the great European powers.

Since the beginning of the war, in September 1939, and subsequently, with the outbreak of the Soviet-Finnish conflict, Britain's attention (first and foremost, but also France's) was drawn towards the possibility, under the pretext of an intervention in favor of Finland, of gaining control over the iron mines in northern Sweden, and over the Norwegian port of Narvik, from where these raw materials took the road to Germany. Under such circumstances, however, it was preferable for Finland to resist as much as it would have kept the Soviet and German troops away from the goals pursued by Britain and France in northern Scandinavia. And Finland, in its turn, would have much to gain in such a context, because control over the northern areas of Norway and Sweden would have allowed the two Western powers to more securely and easily supply the Finnish army with materials and military equipment ${ }^{1}$.

On September 19, 1939, Winston Churchill had raised the issue of Germany's massive imports of Swedish iron ore - of very good quality vital to the Reich's war industry. The First Lord of Admiralty asserted that it was in the interest of Great Britain that these imports be stopped either by pressure on the Oslo government to prevent their transit through Norway, or even by mining the territorial waters of that country². By the by, such an action would have been a flagrant act of aggression towards a neutral state.

Practically, Scandinavian iron ore was transported to Germany in three ways. The first one was the western one, namely through the Norwegian port of Narvik, through the Norwegian and Danish territorial

\footnotetext{
'Jukka Nevakivi, The Appeal that was never made. The Allies, Scandinavia and the Finnish Winter War 1939-1940 (London, C. Hurst \& Company, 1976), 75.

${ }^{2}$ National Archives / National Historical Archives, Bucharest, England Microfilms Fund, Inv. 1085, Reel no. 8, War Cabinet 20, September 19 ${ }^{\text {th }} 1939,115$.
} 
waters, with a usual traffic volume of around 7 million tons per year. However, there was also an eastern way through the seaport of Luleå, which however froze from October to May and then on the Baltic Sea to Germany, with about 4 million and a half tons per year. The last road was the southern one through the Baltic ports of Gövle and Oxelösund, where the lower quality ores from the Grangersterg mines were loaded. Therefore, the Narvik road to the south, the most important for the matter, was the only one that the Allies could block by dams or direct fleet intervention, as the German contingent on the Baltic Sea could not be challenged ${ }^{3}$.

The outbreak of the Soviet-Finnish war prompted Churchill to resume his idea, believing that the possible involvement of Sweden and Norway in the war was in the interest of Great Britain as long as the Royal Navy had control over the seas. If, on the contrary, the two Scandinavian states remained neutral, the only power that would have gained something would have been Germany, because it could use this status of Norway and Sweden to continue, unhindered, to acquire raw materials vital to its war industry. The United Kingdom should therefore have interrupted ship traffic along the Norwegian coast, either by establishing an air base in the Narvik area or even by landing a combined French-British land force in the same region. To Churchill the plan seemed perfectly feasible because, in his opinion, the mountainous terrain of the region made it almost impossible to use tanks, so that it was enough for the British and the French to land only troops of alpine troops and infantry. Subsequently, with the strengthening of control over the northern Scandinavian Peninsula, Great Britain and France could also consider setting up an air base in the southern peninsula to supervise and control the Baltic Sea. For the moment, the British government did not immediately respond to the plan formulated by the First Lord of Admiralty, but concluded that the idea deserved a closer analysis and decided that the chiefs of staff should study it ${ }^{4}$.

\footnotetext{
${ }^{3}$ Ion Lugoșianu, The Drama of Nordic Neutrality, in "The Universe", Bucharest, Year 57, no. 99, Wednesday, April 10 $0^{\text {th }} 1940,1$.

${ }^{4}$ Public Record Office, (C) Crown Copyright 1989, (hereafter P.R.O.), War Cabinet Minutes 1939-1945, WM (1939), November-December 1939, Fiche 15, War Cabinet 118 (39), Neville Chamberlain in the chair, 18 December 1939, 10.30 A.M., 461-462.
} 
The main objective remained to control the port of Narvik and protect it against possible German intervention. To this purpose, Great Britain was considering the gradual deployment of a force of about 100,000 soldiers, along with 50,000 other French soldiers. Initially, however, it was planned to dismantle a semi-brigade - consisting of three battalions - of French alpine troops and a regular British brigade at Narvik, these forces then going eastward along the rail linking mines of iron in northern Sweden, to finally occupy the mining basins of Kiruna and Gälivare. A further force, consisting of five British battalions, was then to occupy three ports in southern Norway to provide an alternative route to aid to Finland and three British divisions (two of which were withdrawn from the expeditionary corps designated to support the western front in France), were to be detached to participate in Sweden's defense against a possible German attack $^{5}$.

As expected, the plan was kept secret, not only for strictly military reasons, but also because of the reserved attitude of the Oslo and Stockholm Governments, not taking into account Germany's predictable reaction. The political leaders in London and Paris had agreed, from this point of view, that the fewer they knew about these plans, the better6.

On the other hand, it is now certain the fact, contested for a while? that Hitler preferred that Norway should remain a neutral country outside the European conflict, Germany's major interest being to ensure its vital raw materials from the Scandinavian region, mainly the Swedish iron ore. The outline of German intervention plans in Norway only materialized when it was clear that the Western allies were planning an intervention in the Scandinavian Peninsula with the clear objective of gaining control over the iron ore deposits in northern Sweden and the means of transport to

\footnotetext{
${ }^{5}$ Max Jakobson, The Diplomacy of the Winter War. An Account of the Russo-Finnish War, 19391940 (Cambridge, Massachusetts, Harvard University Press, 1961), 206.

${ }^{6}$ Documents on Relations between Britain and Finland 1939-1956 Collated for the Finnish-British Historians' Conference, Helsinki, 29-30 th November 2001 (FCO Historians, Record and Historical Department, Foreign \& Commonwealth Office, November 2001), doc. No. 7.

${ }^{7}$ Jacques de Launay, Great Decisions of the Second World War, 1939-1942, Vol. I, Introductive Study and Notes by Florin Constantiniu (Bucharest, Scientific and Encyclopedic Publishing House, 1988), 76.
} 
Germany ${ }^{8}$. On the other hand, from a German point of view, preventive intervention and the possible occupation of Norway before the Allies would have fully secured and ensured the supplies of Swedish iron ore so necessary for the German war industry. In this context, a first order to prepare a contingency plan for the occupation of Denmark and Norway was given by Hitler on December 14, 1939, but the general war directive aimed at putting into practice these plans was only issued on March 1, 1940, when the German leader was convinced that he must get ahead of schedule, at any cost, with the Western plans for a Scandinavian intervention'.

General Titus Gârbea, the Romanian military attaché in the Nordic and Baltic countries, residing in Stockholm between 1940 and 1942, mentions the same considerations in his notes. Interestingly, from this perspective there are the arguments presented to the Romanian attaché by the commander of the German troops in Norway, General Nikolaus von Falkenhorst, who stated that the allied plans aimed at blocking navigation in the Norwegian ports and waters, along with the occupation of the iron mines in the north of the Scandinavian peninsula and depriving Germany of access to these vital resources. In the opinion of the German commander, though, although the plan was vast, its preparation and putting into practice was a lamentable, almost "childish" one. The German general said that the occupation of Norway removed the English danger, the Reich's naval and air bases could more clearly jeopardize the British islands and German submarines and planes now had the opportunity to hit Great Britain much more effectively ${ }^{10}$.

Exactly the same elements and arguments of the importance and prospects of German intervention were also analyzed in an article in the "Aerial Romania" magazine of April 1940. In the authors' opinion, a possible success of the German attack and the occupation of Norway,

\footnotetext{
${ }^{8}$ B. H. Liddel-Hart, The History of the Second World War, Vol. I, Translation: Irina Negrea (Bucharest, Orizonturi Publishing House, Lider Publishing House), 77.

9 Adolf Hitler, War Directives, Romanian version: Dragoș Nedelescu (Bucharest, Elit Publishing House), 73.

${ }^{10}$ Titus Gârbea, Memorial and daily notes, Volume I, Edited and annotated by Silviu Miloiu (Târgoviște, Cetatea de Scaun Publishing House, 2011), 222-223.
} 
which "produced an extraordinary, easy-to-understand emotion throughout the world", would have meant that Germany would dominate the North Sea and diminish the effects of allied blockade, and ensure a wide exit towards the Atlantic. In this perspective, it was considered that Germany could have been able to threaten not only Great Britain, but also Iceland, Greenland or even Canada and eventually the United States of America. On the other hand, the authors of the article were equally surprised by the allied answer to the German action in Norway, with the British and French forces promptly acting against the German troops and making their own landings in Norway ${ }^{11}$. However, the conclusion of the article may seem at least erroneous today, although it was starting from the right premise, but it also reflected the attitude and beliefs of a majority in Europe that still had in mind the lessons and the conduct of the Great War: "the «lightning war» had failed in Norway, in spite of all the admirable conditions in which it was prepared by the Germans. It turns out that for the control of Norway there will be much more struggle than it is generally assumed. The war on these lands will also be long-lasting, like the one on the Western Front."12

Nevertheless, in the Romanian military literature of the times, we also find correct conclusions about the lessons of the war in Norway. This campaign offered the occasion for a first major air-naval confrontation, and its lessons were studied and analyzed immediately. We do not unintentionally highlight this, because the period that followed the Great War was controversial between aviation, now constituted as a weapon and other traditional military structures - the land and navy troops, the first persisting in overestimating its capacity and the others continuing to underestimate it with contempt - that is easy to understand if we take into account the speed of technology development and the inability to efficiently reproduce active service in peacetime. Also, the experience of the first world conflagration has shown that a future conflict will, to a large

\footnotetext{
${ }^{11}$ The Franco-British troops landed at Namsos on April 15, 1940, in Åndalsnes on April 18, and in the north in Narvik on April 19. General Radu R. Rosetti, Lessons from the Ongoing War, Edited and annotated by Maria Georgescu and Andrei Pippidi, Preface by Andrei Pippidi (Bucharest, Curtea Veche Publishing House, 2003), 116. See also de Launay, 78.

${ }^{12}$ A new Theater of War, in "Aerial Romania", Bucharest, year XIV, no. 4, April 1940, 1-2.
} 
extent, be an air war, air supremacy playing an important role in obtaining the battlefield decision. Or the Northern Europe campaign in April-June 1940 showed that, on the one hand, naval supremacy, in the British case, was no longer possible without adequate air protection and, on the other hand, air supremacy did not automatically bring the domination of the seas $^{13}$. Also, by the end of the fighting in Norway, Romanian military authors reported that the British fleet was still in control of the North Sea, despite the significant losses suffered, still being able to cover landings and redevelopments or to support the blockade against Germany ${ }^{14}$. Concerning Germany, the conclusion of the Romanian military authors was that Norway was not conquered by the fleet, but by aviation, the air component of the invasion being decisive both in supporting the ground operations and in supporting the naval actions ${ }^{15}$.

On the other hand, in an intimate meeting of the Romanian Academy, held on May 10, 1940, General Radu Rosetti drew attention exactly to these matters as lessons worthy to be learned even by the Romanian deciders. In addition, General Rosetti pointed out that the German success in Norway had cost the Reich quite a bit of material and military resources, even if the Swedish iron ore route had been secured, and the losses were not negligible at all. Through the Scandinavian campaign, Germany had lost the advantage of a neutral Norway, now firmly backed by Western allies, having to keep there occupational forces that might have been needed in other theaters of operations. On the other hand, Western powers, albeit suffered significant losses, had won an ally, Norway, but their prestige, especially among neutral countries (and so of Romania), had been seriously damaged by the inability to maintain the front in the Scandinavian Peninsula and evacuate its own combat forces from Norway ${ }^{16}$.

\footnotetext{
${ }^{13}$ De Launay, 89.

${ }^{14}$ Al. C. Vissarion, Northern Air-Naval War, in "Aerial Romania", year XIV, no. 4, April 1940, 3.

${ }^{15}$ Colonel Ioan Gheorghe, After a Year of European War. Findings and Reflections for the Future, in "Military Romania", monthly general journal founded in 1864, Bucharest, year LXXVII, No. 9-10, Sept-Oct. 1940, 8.

${ }^{16}$ Rosetti, 116-117.
} 
There have also been serious criticisms of Norway, expressed not only by Romanian soldiers, but also by diplomats although, knowing now the evolution of the events of the times, we can say that Romania did not or did not have time to learn much of the premises and the conduct of the campaign in Norway. Thus, in a report, prepared to be presented to the new Foreign Affairs Minister in Bucharest, Ion Gigurtu, on June 19, 1940, Emil Zarifopol, in charge of Romania's business in Oslo, clearly outlined the causes of German success in Scandinavia. From his point of view, Norway was neither military nor politically prepared to cope with an invasion, the Oslo government believing that it was sufficient to express repeatedly its desire to maintain Norway's neutrality to keep the country safe from an external aggression ${ }^{17}$. Emil Zarifopol had previously qualified this attitude as weakness, incompetence and lack of responsibility ${ }^{18}$.

Although the Norwegian Army had a considerable number of soldiers (about 270,000), it lacked sufficient and competent staff and adequate weapons. In addition, the Romanian diplomat emphasized that the Norwegian army had not even been mobilized after September 1, 1939, when the war broke out in Europe, following the example of most European armies, including those of other neutral states. Only the coastal defense and the fleet had been mobilised, and they had acquitted honourably of their duties during the German invasion. The difficult and vast landscape of Norway, afforested and with few ways of communication, would have served an effective defensive effort on the part of the Norwegian terrestrial troops, had the Finnish will and courage existed. Even after the fighting, the Romanian diplomat remarked, the Norwegians did not realize they were occupied and could no longer do what they wanted in their country, the first civil acts of passive resistance

\footnotetext{
${ }^{17}$ Ministry of Foreign Affairs of Romania, Ministry of Foreign Affairs of Norway, RomanianNorwegian Relations. Diplomatic Documents 1905-1947 (Bucharest, Romanian Cultural Institute, 2007, doc. no. 98), 188-189.

${ }^{18}$ Ibid., doc. no. 97, Telegram of Romania's Business Commissioner in Oslo Emil Zarifopol to Foreign Minister Grigore Gafencu about the German invasion of Norway, the fightings with the invading forces and the exile of the King and a part of the Norwegian Government, 186.
} 
being considered childish, such as the breaking of posters in German and the cutting of queues of girls walking in public with German soldiers ${ }^{19}$.

Moreover, Emil Zarifopol also criticized the allied intervention in Norway. The English and the French, he said, "were not at their best, except for the British fleet, which had some sporadic successes". One of the causes of the allied failure was also the small combat forces deployed by allies on the Norwegian land border, ranging from 800 to 2000 soldiers, "young reserves, incompletely trained, unprotected nor by airplanes, nor by antiaircraft guns". On the other hand, the Germans, in the opinion of the Romanian diplomat, had acted with their usual precision, demonstrating good knowledge of the field in Norway and of the opponent they had to face. A novel and interesting piece of information is also mentioned in this report, namely that the Germans used elements of selected troops that spoke very well Norwegian, being no other than Austrian children adopted by Norwegian families after the First World War and now part of the Austrian alpine troops embedded in the Wehrmacht after Anschluss in $1938^{20}$.

Not even the Oslo officials escaped the criticism of the Romanian diplomat. Norwegian Foreign Minister Halvdan Koht was accused of the fact that, having received credible information about German Navy movements since April 3, he informed the Norwegian Admiralty on April 7 , and brought all this to the attention of the Storting (the parliament) only the following day, but argued alongside the defense minister that German representatives had assured them that they were simply speculation, allegations of the allies. The next day, the Germans disembarked in Oslo ${ }^{21}$.

In the same train of ideas, the Romanian diplomat also underlined the premeditated character of the German action. The authorities had discovered weapons stores and munitions at various strategic points of Norway, along with significant quantities of diverse military equipment. At the same time, ships with alleged German "tourists" had entered the ports of Bergen, Trondheim, Narvik, Stavanger and Kristiansand a few days

\footnotetext{
${ }^{19}$ Ibid., doc. nr. 98, 188-189.

${ }^{20}$ Ibid.,188.

${ }^{21}$ Ibid.,191.
} 
before the invasion and the German supreme commander General von Falkenhorst reported that he had been in Norway for three weeks, with an obviously false identity, impersonating a trader ${ }^{22}$. General Radu Rosetti also mentioned these preparations and diversions in the intimate meeting of the Romanian Academy, which we have already mentioned, being a matter that the Romanian military and Romanian diplomats have emphasized.

If we place the reactions of Romanian military and diplomats to the invasion of Norway in these coordinates, we have to say that the Romanian press reported or attempted to report the events in the Scandinavian region with a special interest, beyond which it can be easily identified a certain emotion and, we are not afraid to say it, sympathy ${ }^{23}$. From the outset, however, the main issue analyzed in the major Romanian central newspapers was that of Nordic neutrality in general and of Norway in particular, given that Romania was at that time a neutral country. In a firstpage editorial of the "Universe" of April 10, 1940, Ion Lugoşianu, director of the daily newspaper, appreciated that the Allies' mining of Norwegian territorial waters, made on April 8, brought with it, legally, a clear aggression of the Scandinavian state's neutrality. Either way, this allied decision showed that the great Western powers were no longer willing to tolerate detrimental neutrality for them, and refused to look for the essence of neutrality in legal arguments, which had created vivid emotions and worries not only in Norway but also in neighboring Sweden ${ }^{24}$.

The same Ion Lugoşianu wrote, the next day, in the "Universe" that the neutrality of Denmark and Norway belongs to the past, Germany occupying Denmark and landing troops in Oslo, Bergen, Trondheim, Kristiansand and Narvik, the capital and ports of a Norway armed only with the legal arguments of neutrality. The Romanian journalist emphasized the advantages gained by Germany through this move.

\footnotetext{
22Ibid.,191-192.

${ }^{23}$ In our approach, we have followed, from this perspective, the accounts of the "Universe" and "Curentul". They seemed to be the most interesting and detailed enough to meet the objectives of the present research, which does not propose, however, an exhaustive analysis of the reactions of the Romanian press of time.

${ }^{24}$ Lugoșianu, 1.
} 
Norway's occupation offered Germany a peripheral position open to the British archipelago over a long stretch of coast, which considerably reduced the effectiveness of the allied blockade, secured imports of Swedish iron ore and permanently blocked the so-problematic access of the allied naval forces to the Baltic Sea. In addition to all these gains, Germany also gained the prospect of much better opportunities to attack Great Britain directly ${ }^{25}$. At the same time, the journalist emphasized Sweden's direct interest in the evolution of the political-military situation in the Scandinavian Peninsula, in the context in which this neutral country also demonstrated that it understood to remain neutral even when, in the opinion of the Romanian journalist, its interests were to make northern solidarity a reality. Or Ion Lugoşianu considered that now Sweden was completely isolated and threatened from all sides, faced with painful choices for itself and for the destiny of Scandinavia ${ }^{26}$, but at the same time it represented the only element capable of producing major changes in the political and strategic equation of the Nordic War27. Moreover, in the April 15, 1940 issue of "The Universe", the Romanian journalist published an editorial, on the front page, in which he precisely analyzed, in detail, the neutrality of Sweden.

A much more intense, more passionate, but also more acidic point of view was expressed by Pamfil Şeicaru in his "Curentul", in relation to the events in northern Europe, appreciating that the Nordic countries were much more evolved as a social organization than most other countries on the old continent because they had not been forced to pay tribute until then to the god Mars. Precisely because of this, Pamfil Şeicaru considers, "by their lack of military organization, by their refractory spirit of the concept of armed peace, crossed and dominated by the pacifism of a very aggressive socialism, the northern countries found themselves in the most awkward situation when Finland was attacked. But they did not dare to directly, resolutely manifest their solidarity, because their military power was so low, their fighting spirit so anaemic, that they thought they could

\footnotetext{
${ }^{25}$ Ion Lugoșianu, North War, in "Universul”, Bucharest, year 57, no. 100, Thursday, April 11 1940, 1-2.

26Ibid.,2.

${ }^{27}$ Ion Lugoșianu, After the First Battles in Norway, in „Universul”, Bucharest, year 57, no. 102, Saturday, April 13 1940, 1.
} 
save their neutrality by a more sentimental than real assistance to Finland. Sweden and Norway - we do not even mention Denmark - have been intimidated by the hypothesis of a simple frown of Germany, which in a panther leap could occupy the whole of the North. It is true that it would have been hard to remove their sliding towards a grip between the two battle lines [German an allied], to become " no man's land», because their ties to Germany - to which they supplied so much raw material - in particular contradicted the Allied blockade policy"28. However, edifying for the Romanian attitude towards the events in Scandinavia, beyond the blunt comments on the northern countries remain, in our opinion, the last two sentences of the editorial published by the famous Romanian journalist: "Today, the northern front has settled. It breathes the countries of Southeast Europe. ${ }^{29 "}$ From our point of view, other comments would be superfluous.

It is not the place and we did not propose in our approach, for a detailed analysis of the Romanian press's reactions to the events on the Scandinavian front. Beyond news, telegrams, editorials, telephone reports of various European capitals correspondents, rumors and denials, from such an analysis, even succinct and not necessarily exhaustive, gets through a sincere interest, doubled by a certain sympathy and warmth towards the fate Norway and Denmark, now occupied by German troops. Not accidentally, both in the "Universe" and in the "Curentul" huge maps in very detailed colors of the Scandinavian Peninsula appear in the era, a very rare fact in the newspapers of the time. It is one of the reasons why, at the beginning of our analysis, we mentioned that the invasion of Norway was a true lesson of Scandinavian geography for the Romanian public, directly interested in the evolution of the European war ${ }^{30}$. In addition, the names of those who signed editorials or broad-based articles about the situation in Norway were those of well-known personalities from the Romanian media landscape of the time such as Ion Lugoşianu, Pamfil Şeicaru or Romulus

\footnotetext{
${ }^{28}$ Pamfil Șeicaru, The Northern Front has Settled, in "Curentul”, Bucharest, Year XIII, No. 4369, Thursday, April 11 1940, 1.

${ }^{29} \mathrm{Ibid}$.

30 See "Curentul”, Bucharest, Year XIII, No. 4378, Saturday, April 20 1940, p. 1 and „Universul”, Bucharest, Year 57, no. 118, Thursday, May 2 1940, 6.
} 
Seişanu, which once again highlights the importance of the subject for the Romanian audience of those years.

Beyond the reality and the unfolding of the war, the Romanian central newspapers also offered the public other images of the Scandinavian countries, which readers now seemed to truly discover. Even the titles of such articles emanate, as we have said, warmth and sympathy. A good example of this is that on one newspaper page, in the April 19 issue of "Curentul", we find three ample articles devoted to Denmark, Norway and Sweden, whose titles no longer need any comment: Norway, the Country of the Fjords and the 150,000 Islands; Denmark, the Region of Wise and Hardworking Farmers and Fishermen; Sweden, the Homeland of Ion Ore.Moreover, the "Universe" published in the last pages of its May 11, 1940 issue a short article, entitled How to Pronounce Norwegian Words? Some Explanations for Those who are Following the Struggles on the Northern Front, which clearly shows the interest of the public in this direction and, equally, the editorial staff's concern to meet the most diverse expectations of the readers.

Last but not least, we mention a special article, published in the May 3, 1940 issue of the "Universul" newspaper, in the so-called "Women's Page" and entitled Views to the Northern World, among which the Romanian readers were invited to discover the nature of the people from the north, literature, position and emancipation of women in northern Europe. Not giving a few short quotations of this article means to deprive today's reader of some special echoes of the Scandinavian war: "Love [in the north] does not have the expansion of the fires lit in the Mediterranean, nor does it get close to the romantic sentimentalism of the Germans. There is a tendency that does not want to show itself, an inclination that likes to take an unobtrusive, unhindered look, to be free. The man in the north does not bind his life to any constraint. He is wearing an ideal to which he is heading with some sort of imagery, but he moves away from such a strong feeling as the love that seems a burden to him. (...) The woman is independent and individualistic. She is confident in her value and has the consciousness of the dignity of sex. She overcame the obstacles that cut her way, and before her fellows in other countries, she conquered all rights. She 
works alongside men, like them, work not seeming to be anything special. The taste of working is the price of the won freedom. Respect for work makes her the man's companion."

In the end, it should be noted that the start of military operations on the western front on May 10, 1940 almost completely shadowed the Scandinavian drama and the Norwegian war. Everyone's eyes were on their way to the new clash of the old Great War adversaries. Norway was forgotten, but certainly, the Scandinavian campaign represented, at least in Romania and for the Romanians, an open door to a world that was not known until then. 


\section{Bibliography:}

National Archives / National Historical Archives, Bucharest, England Microfilms Fund, Inv. 1085, Reel no. 8, War Cabinet 20.

Public Record Office, (C) Crown Copyright 1989, (hereafter P.R.O.), War Cabinet Minutes 1939-1945, WM (1939), November-December 1939, Fiche 15, War Cabinet 118 (39).

\section{Published documents, memoires, and diaries:}

Documents on Relations between Britain and Finland 1939-1956 Collated for the Finnish-British Historians' Conference, Helsinki, 29-30 th $N$ November 2001. FCO Historians, Record and Historical Department, Foreign \& Commonwealth Office, November 2001.

Gârbea, Titus. Memorial and daily notes, Volume I, Edited and annotated by Silviu Miloiu. Târgoviște, Cetatea de Scaun Publishing House, 2011. Hitler, Adolf. War Directives, Romanian version: Dragoș Nedelescu. Bucharest, Elit Publishing House.

Ministry of Foreign Affairs of Romania, Ministry of Foreign Affairs of Norway, Romanian-Norwegian Relations. Diplomatic Documents 19051947. Bucharest, Romanian Cultural Institute, 2007.

\section{Books:}

Jakobson, Max. The Diplomacy of the Winter War. An Account of the RussoFinnish War, 1939-1940. Cambridge, Massachusetts, Harvard University Press, 1961.

de Launay, Jacques. Great Decisions of the Second World War, 1939-1942, Vol.

I, Introductive Study and Notes by Florin Constantiniu. Bucharest, Scientific and Encyclopedic Publishing House, 1988.

Liddel-Hart, B. H. The History of the Second World War, Vol. I, Translation: Irina Negrea. Bucharest, Orizonturi Publishing House, Lider Publishing House.

Nevakivi, Jukka. The Appeal that was never made. The Allies, Scandinavia and the Finnish Winter War 1939-1940. London, C. Hurst \& Company, 1976. 
General Rosetti, Radu R. Lessons from the Ongoing War, Edited and annotated by Maria Georgescu and Andrei Pippidi, Preface by Andrei Pippidi. Bucharest, CurteaVeche Publishing House, 2003.

\section{Newspaper articles:}

A new Theater of War, in "Aerial Romania", Bucharest, year XIV, no. 4, April 1940, 1-2.

„Curentul”, Bucharest, Year XIII, No. 4378, Saturday, April 201940.

Colonel Gheorghe, Ion. After a Year of European War. Findings and Reflections for the Future, in "Military Romania", monthly general journal founded in 1864, Bucharest, year LXXVII, No. 9-10, Sept-Oct. 1940.

Lugoșianu, Ion. After the First Battles in Norway, in „Universul”, Bucharest, year 57, no. 102, Saturday, April 131940.

Lugoșianu, Ion. North War, in "Universul”, Bucharest, year 57, no. 100, Thursday, April 111940

Lugoșianu, Ion. The Drama of Nordic Neutrality, in "The Universe", Bucharest, Year 57, no. 99, Wednesday, April 10 1940.

Șeicaru, Pamfil. The Northern Front has settled, in "Curentul", Bucharest, Year XIII, No. 4369, Thursday, April 111940.

Universul", Bucharest, Year 57, no. 118, Thursday, May 21940.

Vissarion, Al. C. Northern Air-Naval War, in "Aerial Romania", year XIV, no. 4, April 1940. 